\title{
MEMORIAS DEL SILENCIO. LITERATURAS EN EL CARIBE Y EN CENTROAMÉRICA, DE GRACIELA SALTO ${ }^{1}$
}

Carmen Perilli

n el prólogo de la compilación la investigadora Graciela Salto se refiere
al silencio como rasgo intrínseco de las literaturas y culturas del Caribe,
al que ve como "un mar que no concentra relatos sino que los difracta y los expele con la fuerza emanada de una metáfora centrífuga”. Un mundo devastado por su historia de dominaciones coloniales y marcado por la particular geopolítica cuya heterogeneidad y dispersión dificulta la elaboración de modelos explicativos. Memorias del silencio reúne un sólido conjunto de textos y estudios organizados en tres partes.

La primera, "Traducciones y difracciones en el Caribe", se inicia con la trascripción del diálogo entre dos figuras centrales del Caribe anglófono y francófono: el poeta Kamau Brathwaite (Barbados) y el intelectual Édouard Glissant (Martinica). Se refieren a la necesaria descolonización cultural que, en primer lugar, exige la difícil comunicación entre los distintos "caribes", unidos por "memorias volcánicas", inscripta en el genocidio histórico y la catástrofe geológica. Brathwaite expresa "Hemos en cierto modo perdido el sentido del continente, el sentido de la totalidad y nos hemos convertido en agujeros en el océano". El lenguaje-nación confrontado con la lengua oficial lleva a indagar las posibilidades del créole como lengua de mezcla. Al mismo tiempo destaca la poética de "acriollamiento" y la recuperación del "paisaje" en su fuerza y peculiaridad. El modelo cultural es la raíz, una y múltiple, abierta y proliferante hacia fuera, como sola posibilidad de establecer comunicaciones entre los diversos Caribes y preservar lógicas culturales múltiples y diversas. Carolina Benavente Morales, traductora de la conversación, reflexiona sobre su trabajo y propone claves de comprensión de las culturas sometidas a la operación de

1 Memorias del silencio. Literaturas en el Caribe y en Centroamérica. Edición, compilación y prólogo de Graciela Salto. Buenos Aires: Corregidor, 2010. 
traducción. El texto de Irmtrud König se centra en Aimé Césaire cuyo teatro actúa como vehiculo de descolonización. El análisis aborda La tragedia del rey Christophe. Otro trabajo sugerente es el de Alejandra Olivares sobre Jamaica Kincaid quien traduce dos relatos que escenifican el "dilema del escritor caribeño": "Girl” de Jamaica Kincaid y su reescritura paródica "Girldfriend" de Michael Thomas Martin.

La segunda parte del libro se concentra en Cuba, en especial en la etapa posterior a los 80. En un pormenorizado texto Graciela Salto se refiere a dos rasgos propios de las prácticas culturales cubanas: el "choteo" y la "suave risa". Recorre las lecturas realizadas por intelectuales como Jorge Mañach y Fernando Ortiz, Cintio Vitier y Severo Sarduy para detenerse en la créolisation del choteo de Gustavo Pérez Firmat y en su empleo como estrategia camp en José Esteban Muñoz. María Virginia González y María Fernanda Pampín insisten en la Cuba que se inicia en el "Período especial", analizando las escrituras del derrumbe. González aborda el análisis del ensayo de Margarita Mateo Palmer para examinar la ruptura en la extensa tradición del ensayo cubano, dominada por voces masculinas. María Fernanda Pampín indaga sobre la invención de la ciudad en Abilio Estévez demostrando que no sólo se trata de una nueva mirada múltiple sobre La Habana - un "inventario" que colecta diversas versiones sobre la ciudad tomadas tanto de relatos de escritores cubanos clásicos y novísimos, como de los recuerdos personales del narrador que conforman una ciudad secreta y personal. El texto se construye en el cruce entre la literatura de viajes, memorias y ficción.

Otros trabajos regresan con insistencia a la configuración de los imaginarios nacionales en los orígenes de los Estados latinoamericanos, desde una perspectiva atenta a las heterogeneidades contenciosas que desafían sus umbrales, y alerta ante las complejidades y contradicciones que las fraguas de proyectos identitarios procuraban suturar en su intento por negociar los espacios subalternos. María Pía Bruno bucea en las configuraciones imaginarias de lo cubano delineadas bajo el impacto de crecimiento de la industria azucarera en la isla, en el romancero escrito entre 1830 y 1880 al calor del proyecto cultural y literario de Domingo del Monte (1804-1853) y su círculo literario, cuyos miembros adherían al ideario ilustrado y reformista del momento. Además, presta atención a la arquitectura del "romance de tema patriótico" y sus capacidades como género para organizar la imagen de la cubanidad 
(la oralidad, los vínculos entre tradición y renovación, la tendencia narrativa y explicativa). Ariela Schnirmajer analiza la presencia en ciertos textos martianos de figuras femeninas que intervienen en textos de José Martí.

La tercera parte del libro reúne ensayos sobre literatura y cultura centroamericana. Mónica Marinone se centra en la narrativa venezolana del siglo XX para luego explorar la desconstrucción de la leyenda nacional en un trayecto que va desde Las lanzas coloradas (1931), Arturo Uslar Pietri hasta La carujada (1990) de Denzil Romero. Centra su mirada en el anti-héroe Pedro Carujo y descompone la mitología heroica de Bolívar empleando una serie de prácticas perturbadoras. Diana Moro reflexiona sobre Castigo divino la novela del nicaragüense Sergio Ramírez. María Teresa Sánchez propone analizar la escritura de Monterroso. María del Pilar Vila nos introduce en la "nueva narrativa centroamericana" de los años 90 que exhibe los avatares de un territorio convulsionado, sometido a vaivenes políticos, económicos, sacudido por la violencia, con las heridas de las recientes guerras aún abiertas, gobernado por poderes corruptos, para trabajar con las ficciones de Horacio Castellanos Moya. La "violencia" se constituye en el núcleo de estos relatos donde se apela "a la injuria y a la violencia como modos de socavar certezas".

En suma, el libro resulta un excelente camino para comprender el universo cultural caribeño, en especial sus literaturas. Exhibe la atrayente cualidad de la heterogeneidad ya que los distintos textos aportan abordajes diversos de género, inclusive exploran formas diversas de escribir crítica y teoría literaria y cultural.

Recebido em: 27/03/12

Aprovado em: 28/11/12 